\title{
Critical Examination Using Business Intelligence on the Gender Gap in Information Technology in Brazil
}

\author{
Erica L. Gallindo (D), Hobson A. Cruz (D) and Mário W. L. Moreira *(D) \\ Federal Institute of Education, Science, and Technology of Ceará, Fortaleza 60410-426, Brazil; \\ erica.gallindo@ifce.edu.br (E.L.G.); hobson.cruz@ifce.edu.br (H.A.C.) \\ * Correspondence: mario.wedney@ifce.edu.br; Tel.: +55-85-99916-0886
}

\begin{abstract}
In the early 1990s, cyberfeminism emerged as an area of knowledge to discuss the connection between gender and technology. According to UNESCO, women are underrepresented in the field of science, technology, engineering, and mathematics and less than a third of women worldwide work in scientific research and development. However, this number has grown and this reality is constantly changing. In this context, using business intelligence techniques, this study analyzes data from the computer and information and communication technology market to characterize the impact of the performance of women in these areas. It is expected to show that this performance in the highlighted fields is still a challenge in Brazil. Based on this hypothesis, results indicates that public policies must be focused on the base, i.e., to encourage young women to work in STEM areas. This study could encourage policymakers to find solutions to the challenges presented in this research.
\end{abstract}

check for updates

Citation: Gallindo, E.L.; Cruz, H.A.; Moreira, M.W.L. Critical Examination Using Business Intelligence on the Gender Gap in Information Technology in Brazil. Mathematics 2021, 9, 1824.

https://doi.org/10.3390/math9151824

Academic Editor: Amir Mosavi

Received: 27 May 2021

Accepted: 29 July 2021

Published: 2 August 2021

Publisher's Note: MDPI stays neutral with regard to jurisdictional claims in published maps and institutional affiliations.

Copyright: (C) 2021 by the authors. Licensee MDPI, Basel, Switzerland. This article is an open access article distributed under the terms and conditions of the Creative Commons Attribution (CC BY) license (https:/ / creativecommons.org/licenses/by/ $4.0 /)$.
Keywords: business intelligence; gender gap; information technology; STEM education in Brazil

\section{Introduction}

According to a recent study by the International Labor Organization (ILO) (Available at https: / / www.ilo.org/global/about-the-ilo/newsroom/news/WCMS_619550?lang=es (accessed on 26 May 2021)), launched on the eve of International Women's Day, women are less likely to participate in the labor market than men and are more likely to be unemployed in most countries worldwide [1]. In 2018, the overall rate of participation of women in the workforce is around $48.5 \%$, while that of men is 75\% (cf. https: / / www.ilo.org/brasilia /noticias/WCMS_615927/lang--pt/index.htm (accessed on 26 May 2021)). According to data from the McKinsey Global Institute, advancing equity in women's participation can contribute to an increase of US\$ 12 trillion in the Gross Domestic Product (GDP) of nations by 2025 (Available at http:/ / www.mckinsey.com/global-themes / employment-and-grow th/how-advancing-womens-equality-can-add-12-trillion-to-global-growth (accessed on 26 May 2021)). Considering only the Brazilian context, the ILO research pointed out that reducing gender differences in the labor market could increase the national GDP by 3.3\%, i.e., $\mathrm{R} \$ 382$ billion [2].

In accordance with Sustainable Development Goal 5 (SDG 5) (Available at https:/ / ww w.ipea.gov.br/ods / ods5.html (accessed on 26 May 2021)). Of the 2030 Agenda of the United Nations (UN), public policies must be aimed at reducing gender inequality, promoting greater autonomy for all women at their various intersections, such as race, ethnicity, age, among others [3]. Only through the recognition and appreciation of women's work in society, through the provision of public services, infrastructure, and social protection policies, as well as the promotion of shared responsibility within the home and family, is it possible to reduce these inequalities.

According to Ferreira and Lucchese [4], from 2014-2024, efforts by governments and civil society organizations will not be sufficient concerning the reduction of gender inequalities [5-7]. In [8], the authors suggest that continued support and the development of new efforts 
are needed to change society's perceptions of the role of women in technology so that young students, as they progress through high school and find out-of-school experiences, enter courses in the STEM areas (STEM is an acronym for science, technology, engineering, and mathematics).

In 2017, in higher education, women represented $45 \%$ of students enrolled in STEM courses. In the technology market, they accounted for $20 \%$ of jobs, while in the academy, only $28 \%$ of researchers were women [9]. However, Casad et al. [10], in a first known cross-sectional study on the topic in its entirety, identified that the completion rates of bachelor's degrees in STEM are higher among women. The authors argue that the variables and relationships tested in the model of conservative academic environments can help explain the underrepresentation of women in these areas.

The study presented by Keune et al. [11] suggests that young women today have greater recognition in the technology job market, thus increasing the opportunity to develop more meaningful projects. In time, these opportunities can also extend beyond the cognitive development of young people and begin to drive a new recognition of the STEM experience in traditionally underrepresented young women, which ultimately translates into more learning opportunities and paths of learning. career for this group [12]. In addition, the case provides starting points for encouraging opportunities for greater recognition of the STEM specialty for women.

Poggesi et al. [13] found that, currently, women's work has expanded the frontiers of research in the areas of STEM, specifically, there is well-established evidence on the female empowerment of technology despite several difficulties, e.g., related to funding and gender-related obstacles. In [14], the authors suggest that innovative approaches to professional development have contributed to addressing the lack of women leaders in fields related to science and technology. In this study, projects with the immersion of professional development for women based on research were discussed. Given this, these innovative projects have enabled women to be equipped with the ability to navigate the complexity of non-traditional professions. The initial analysis of the results of these projects shows increases in the participant's self-awareness, self-efficacy, and ability to persist and stand out in the chosen profession. The results provide encouraging indicators of the success of the intervention through these policies in advancing and retaining women in the areas of STEM and various related professions.

In this context, the main contributions of this paper are:

- Collect data from the most recent Annual Social Information List (RAIS), identifying which information should be admitted for this research;

- Identify with the Brazilian Classification of Occupations (CBO) which are the occupations of unique interest for this study;

- Treat the data acquired using business intelligence (BI) techniques to determine the real impact of the growth of female performance in the area of Computer Science and Information and Communication Technology (ICT) - a subset of the STEM area considering age range, salary, and other relevant indicators.

The rest of this paper is organized as follows: Section 2 presents the works related to this study; Section 3 presents the theoretical framework that guided this research, namely, concepts of business intelligence; Section 4 presents the research methodology; Section 5 shows the results obtained; and finally, the final considerations are presented in Section 6.

\section{Related Works}

Second Emerging Professions Report for 2020 from the LinkedIn platform for Latin America (Available at https://business.linkedin.com/content/dam/me/business/en-us/ talent-solutions / emerging-jobs-report/Emerging_Jobs_Report_Brazil.pdf (accessed on 26 May 2021)), in the digital age, professions related to Information Technology (IT) are in an increasing trend $[15,16]$. About 9 of the 15 rising professions were linked to this area. Among the productive chains that most demand services are that of IT. These services have been mapped between the three sectors most interested in 11 of the 15 emerging 
professions, i.e., IT and services [17]; software for computers [18] and financial services [19]. The Internet and computer software segments also appear as the main contractors for 11 rising careers. In this context, studies of the current state of the art sought to identify the growth in the performance of women in these segments.

\subsection{Cybersecurity Engineering}

Dunn and Merkle [20] discuss, in their study, the problem of gender imbalance and other underrepresented categories, arguing that only $11 \%$ of cybersecurity professionals are women. The authors assessed the impact of extracurricular cybersecurity competitions, e.g., CyberPatriot, which is the largest cybersecurity competition for elementary and high school students in North America, with the participation of more than 14,000 young people during the school year 2016-2017. The authors found that this type of event narrows the gap between male and female students with regard to their interest in cybersecurity careers. The young women interviewed in the survey, who are ex-participants in the event, reported that they followed courses and careers in computing and cybersecurity. Among women enrolled in higher education, who participated in the competition, $53.6 \%$ were graduating in cybersecurity or computer science, and $80.6 \%$ of young women who were finishing high school reported interest in these areas.

\subsection{Artificial Intelligence Specialist}

Hoffman and Friedman [21] demonstrated that, in 2013, in the world, women obtained $57.3 \%$ of bachelor's degrees in all areas and $50.3 \%$ of science and engineering diplomas. The authors pointed out that there is an increase in the number of women working in areas such as health, education, military, environmental studies, and crime prevention. The main tools used for the transformation of these areas are artificial intelligence and machine learning.

\subsection{Data Science and Engineering}

In [22], the authors sought to quantify the gender gap to identify fields that will not reach parity without intervention, revealing underestimated prejudices and providing references for gender balance among conference speakers, editors, and hiring committees. This study pointed out that, in most of the disciplines represented in the research, the prevailing conventions about the order of authorship mean that the first authors are generally researchers at the beginning of their careers, while the last authors tend to be comparatively senior. Thus, the results suggest that early-stage researchers in these areas are more likely to be women and senior researchers are more likely to be men.

\section{Evolution of the Business Intelligence towards Advanced Data Analysis}

BI-based systems seek to support decision-making in several organizations [23]. The developers of these information systems need to have a good understanding of the organization's decision tasks and work with decision-makers to improve the effectiveness of this decision. This is a difficult and challenging environment for IT developers, as it is an environment in which functional BI systems outperform conventional enterprise systems.

As suggested by the literature, this study considered the level of analysis at which BI is applied [24]. Although the organizational level of analysis is the main focus of recent state-of-the-art articles, and the individual level of analysis has received moderate attention, it is considered that little attention has been paid to the other levels.

- Individual level: BI systems help to improve the decision-making performance of individuals, allowing the creation of meaning in data exploration tasks. This approach facilitates the analysis of large volumes of data and knowledge enrichment.

- Team/group level: The adoption of BI can increase team productivity, facilitating coordination and collaboration, streamlining the collection and analysis of project documents throughout the project's life cycle. 
- Organizational level: there are positive correlations between BI and productivity. For example, at the macro level, the business value of BI is largely supported by the success of conversion and management, including the success of organizational implementation, project implementation, and technical implementation. At the microlevel, technical BI issues are more likely to vary with the nature of the BI infrastructure design of individual companies.

- Industrial level: you can see the positive impacts of BI on the industry's productivity [25]. For example, the adoption of BI in public health can accelerate the process of understanding health issues and responding to crises. Likewise, the adoption of BI in the banking sector can increase fraud detection and response. Meanwhile, at the social level, BI systems support cities to increase the base of active loyalty card users to promote the participation of their citizens in the cultural services offered [26].

In general, there are very few multilevel studies in the literature. However, the impact of BI-based information systems on productivity is generally more positive in surveys that have better data sources, refined measures of productivity, and a better consideration of the aspects of managing information systems.

In this context, we chose to use the software Tableau (Available at https: / /www.tablea u.com/ (accessed on 26 May 2021)), From the American company Tableau Software, which is the leader in the development of software for data visualization. Tableau has several interactive features, so you can use different data sources. There is a wide variety of charts available, including standard bars, line, and pie charts, heat maps, highlight tables, and tree maps [27]. There are several reasons why Tableau became popular. First, no specialized knowledge is required to create data visualizations. Even a novice researcher can create graphics relatively quickly by downloading the tool. Secondly, it is free, including a full version for academics; in an era of shrinking budgets, this is extremely important. Third, it allows rapid analysis on a large scale and can make sense of huge and complex data sources. Finally, the high-impact visuals that can be created in Tableau have great potential to improve communication with stakeholders. Figure 1 presents a dashboard created from RAIS data.
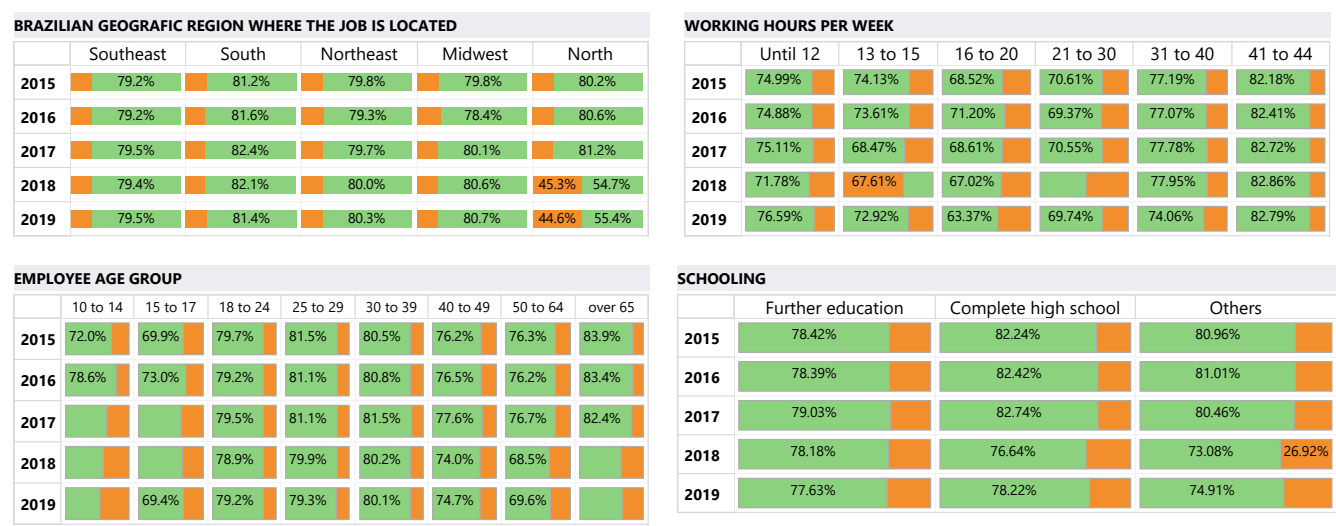

Figure 1. Analysis of the labor market in Information Technology using data from the Annual List of Social Information (RAIS) for the years 2015 to 2019.

The next section discusses the methods used in this research, as well as the database used and the attributes considered.

\section{Data Description and Research Method}

The RAIS was created by Decree ${ }^{\circ}$ 76,900, of 23 December 1975 (Available at http:/ / www.planalto.gov.br/ccivil_03/decreto/antigos/d76900.htm (accessed on 26 May 2021)). Since then, all employers have been obliged to provide, on an annual basis, data on the employees with whom they maintained employment in a given base year, the available data allow a series of analytical cuts to be made considering several aspects, e.g., region, 
economic sector, occupation, sex, education level, age group, among others. The RAIS has enormous potential concerning issues related to the formal labor market in Brazil.

For the definition of occupations in the IT area, 6 subgroups ( 3 digits of the CBO occupation), 2 complete, and 4 partial subgroups were considered, according to the CBO (The CBO is a document that portrays the reality of the professions in the Brazilian labor market. It was instituted with legal basis in Ordinance MTE No. 397, of 10 October 2002). Table 1 shows the subgroups considered in this study.

Table 1. Occupations considered in this research, considering the Brazilian Classification of Occupations (CBO).

\begin{tabular}{|c|c|c|}
\hline Subgroup & Description & Considered Occupations \\
\hline Subgroup 212 & Computer professionals & Complete \\
\hline Subgroup 317 & Computer technicians & Complete \\
\hline $\begin{array}{l}\text { Subgroup } 203 \\
203105\end{array}$ & $\begin{array}{c}\text { Researchers } \\
\text { Researcher in computer science and informatics }\end{array}$ & Partial, only 1 occupation \\
\hline $\begin{array}{c}\text { Subgroup } 123 \\
123605\end{array}$ & $\begin{array}{l}\text { Support area directors } \\
\text { Director of Information Technology }\end{array}$ & Partial, only 1 occupation \\
\hline $\begin{array}{c}\text { Subgroup } 142 \\
142505 \\
142510 \\
142515 \\
142520 \\
142525 \\
142530 \\
142535\end{array}$ & $\begin{array}{c}\text { Managers } \\
\text { Information Technology Infrastructure Manager } \\
\text { Systems Development Manager } \\
\text { Information technology operation manager } \\
\text { Information technology project manager } \\
\text { Information Security Manager } \\
\text { Information technology technical support manager } \\
\text { Technologist in information } \\
\text { technology management }\end{array}$ & Partial, 7 occupations \\
\hline $\begin{array}{l}\text { Subgroup } 234 \\
234120\end{array}$ & $\begin{array}{c}\text { Higher Education Teachers } \\
\text { Computer teacher (in higher education) }\end{array}$ & Partial, only 1 occupation \\
\hline
\end{tabular}

Other sources of data used were the School Census, which is the main instrument for collecting basic education information and the most important Brazilian educational statistical research; and the Higher Education Census, which is the most comprehensive research instrument in Brazil on higher education institutions (HEIs) that offer undergraduate courses and specific training sequences, in addition to their students and teachers. Both are carried out annually by the National Institute of Educational Studies and Research Anísio Teixeira (INEP).

The CINE (The International Standardized Classification of Education (CINE) is a classification developed by the United Nations Educational, Scientific and Cultural Organization (UNESCO) to allow comparison of statistics and educational policies among different educational systems, and is used by INEP to categorize courses in the Higher Education Census). area of the Higher Education Census considered in this study was that of Computing and Information and Communication Technologies. Table 2 shows the courses belonging to this area, as well as the number of enrollments in these courses.

Considering the data collected from these three main sources, this study raised the following hypotheses based on the current state-of-the-art studies-presented in Section 2, which considered the impact of female performance in STEM.

- H1: Early career researchers are more likely to be women in STEM;

- H2: In STEM there is an increase in the number of female students and graduates;

- H3: In some IT-related professions, it is possible to perceive greater female performance, especially middle-aged women and in more specialized positions.

This study is based on RAIS, the School Census, and the School Census of Higher Education sources to validate or refute these hypotheses. This research verify if there is convergence (or not) among the findings of studies of worldwide scope and the Brazilian reality, observing similar patterns. This result strengthens the vision of women's performance in STEM areas in different locations and realities. 
These hypotheses will be discussed in the next section, using clippings that represent the areas of computing and IT in the various contexts analyzed.

Table 2. Computing and Information and Communication Technologies Area, according to the International Standardized Classification of Education (CINE), from the Higher Education Census.

\begin{tabular}{cccc}
\hline Course Name (INEP) & Fem. & Male & Grand Total \\
\hline Grand Total & $\mathbf{4 4 , 4 5 2}$ & $\mathbf{2 8 6 , 9 2 4}$ & $\mathbf{3 3 1 , 3 7 6}$ \\
\hline Analysis and Systems Development & 16,351 & 99,987 & 116,338 \\
Computer Science & 6878 & 54,858 & 61,736 \\
Information Systems & 7684 & 47,982 & 55,666 \\
Information Technology Management & 5436 & 26,236 & 31,672 \\
Computer Networks & 1434 & 16,230 & 17,664 \\
Computer Engineering & 1313 & 9793 & 11,106 \\
Information System & 1452 & 9129 & 10,581 \\
Systems for Internet & 1839 & 7809 & 9648 \\
Software Engineering & 1162 & 8058 & 9220 \\
Digital Games & 903 & 6842 & 7745 \\
\hline
\end{tabular}

\section{Discussion and Analysis of Results}

In this section, the hypotheses raised from the related work analyzed are discussed, using data from the formal labor market and educational training at the basic and higher levels. The data used come from RAIS 2015-2019, the School Census 2020, and the Higher Education Census 2019, i.e., the most recent data available.

Hypothesis 1. Early career researchers are more likely to be women in STEM.

The RAIS data does not support this hypothesis. In fact, in 2019, 68 women and 219 men have admitted to the occupation "Researcher in computer science and informatics". In the last 5 years, the female insertion in this field has been falling, representing $23.4 \%$ of the occupants of these vacancies in 2015 to $18.9 \%$ in 2019. Figure 2 presents this information.

\begin{tabular}{|l|l|l|l|l|l|}
\hline & $\mathbf{2 0 1 5}$ & $\mathbf{2 0 1 6}$ & $\mathbf{2 0 1 7}$ & $\mathbf{2 0 1 8}$ & $\mathbf{2 0 1 9}$ \\
\hline $\begin{array}{l}203 \text { - Research in } \\
\text { computer science } \\
\text { and informatics }\end{array}$ & $76.6 \%$ & $77.5 \%$ & $79.8 \%$ & $81.5 \%$ & $80.7 \%$ \\
\hline
\end{tabular}

Figure 2. Data from the 2015-2019 Annual List of Social Information (RAIS) on the performance of men and women in scientific research.

Hypothesis 2. In STEM there is an increase in the number of female students and graduates.

In 2019, only $14.64 \%$ of current enrollments in the "Computing and Information and Communication Technologies (ICT)" area are women. The situation is even more alarming in baccalaureate courses, where this percentage is even lower (12.39\%). Proportionally, considering baccalaureate and technological courses, only $13.59 \%$ are women. Table 3 shows the percentage between men and women in different teaching modalities in the years 2020 (Higher Education) and 2021 (Propaedeutic and Integrated High School).

In propaedeutic high school, gender inequality is lower compared to other teaching modalities. This research considers that the cause of this is the so-called gender disparity, i.e., young women when they finish propaedeutic teaching seek other areas, other than STEM, as they consider the latter more favorable to men.

Hypothesis 3. In some IT-related professions, it is possible to perceive greater female performance, especially middle-aged women and in more specialized positions. 
The RAIS 2015-2019 data do not prove this. The situation in Brazil is one of very high gender inequality in the most specialized professions in the IT area. If the subgroup "Director of information technology", e.g., is considered, in 2019 only 16.3\% of those admitted are women. If everyone who was working that year is considered, there are $83.7 \%$ of men playing these roles in the formal job market. Figure 3 shows this data.

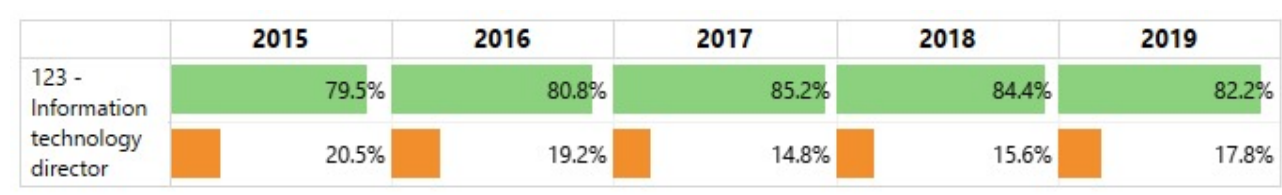

Figure 3. Data from the 2015-2019 Annual List of Social Information (RAIS) on the performance of men and women in specialized positions.

Table 3. Percentage between men and women enrolled in various teaching modalities, considering the School Census and the Higher Education Census.

\begin{tabular}{|c|c|c|c|c|c|c|}
\hline Education Level & Year & Group & Fem. & Male & Fem. & Male \\
\hline University Graduate & 2019 & $\begin{array}{c}\text { CINE Area-Computing and } \\
\text { Information and Communication } \\
\text { Technologies (ICTs) }\end{array}$ & $14.64 \%$ & $85.36 \%$ & - & - \\
\hline Integrated Technician & 2020 & $\begin{array}{l}\text { All classes of 1st Year of Education } \\
\text { Integrated Technician of All } \\
\text { Technological Axes }\end{array}$ & $51.24 \%$ & $48.76 \%$ & 124,089 & 118,066 \\
\hline Integrated Technician & 2020 & $\begin{array}{l}\text { All 1st Year Classes of Integrated } \\
\text { Technician of the Information and } \\
\text { Communication Technological Axis }\end{array}$ & $39.63 \%$ & $60.37 \%$ & 22,408 & 34,130 \\
\hline $\begin{array}{l}\text { Propaedeutic } \\
\text { Medium }\end{array}$ & 2020 & $\begin{array}{l}\text { All 1st Year Classes of Propaedeutic } \\
\text { High School }\end{array}$ & $49.22 \%$ & $50.78 \%$ & $1,327,058$ & $1,368,919$ \\
\hline $\begin{array}{l}\text { Propedeutic Medium } \\
\text { and Integrated }\end{array}$ & 2020 & $\begin{array}{l}\text { All Classes of 1st Year of Education } \\
\text { Propaedeutic and Technical } \\
\text { Education Integrated of the } \\
\text { Information and } \\
\text { Communication Axis }\end{array}$ & $49.03 \%$ & $50.97 \%$ & $1,349,466$ & $1,403,049$ \\
\hline
\end{tabular}

\section{Conclusions and Future Work}

The object of this study, due to its complex phenomenon, has several reasons that may justify a tendency contrary to what occurs in the world in general. Certainly, many of them are related to gender stereotypes, which are the beliefs that there are roles that must necessarily be played by women or that some activities are better performed by men, such as the STEM areas, for example. Several studies demonstrate the impact of these beliefs on the professional career of women. According to research by Harvard University professor Katherine Coffman, gender stereotypes make women feel less confident when working in certain areas and do not value positive feedbacks about their work-the so-called "impostor syndrome"-failing to express their ideas in the professional environment, considering that they are not as valuable or relevant as that of their male colleagues.

The fact is that public policies must be focused on the base, i.e., to encourage young women to work in STEM areas. According to the data collected in this research, 51.25\% of enrollments for all years of propaedeutic high school in 2020 were female students, however when considering only those enrolled in the 1st year, this percentage drops to $49.22 \%$ requiring a longitudinal analysis to understand if there is a phenomenon of reduction of female participation in high school. In the integrated technical courses, female participation was $48.76 \%$ in 2020, but when considering the enrollments of the Information and Communication technological axis, this percentage drops to $39.63 \%$, showing the distance of women from these areas of STEM. Still in the line of training, women are the majority in enrollments in 2019 with $57.03 \%$ of the total but in the IT area, this percentage drops dramatically to $14.64 \%$ of female participation in this universe. The research also 
shows that only $21.12 \%$ enter the job market in occupations related to this same area. Therefore, effective government intervention and public policies are needed to change this reality in Brazil.

The study limitations are related to the database used. The RAIS has a large amount of information about the formal labor market. However, caution is recommended when using and interpreting the data, considering its advantages and limitations. Although RAIS has the advantage of its comprehensiveness, since it allows the crossing of variables, encompassing occupational, sectoral, and geographic levels, its limitation is the declaration omission of organizations, followed by filling errors, resulting from incomplete or incorrect information. Another problem identified is related to the aggregated declarations in the matrix, when it would be correct to provide the information by organization.

Suggestions for further work are related to extending the research period in the databases used to verify real trends, as well as increasing the scope with other data sources. An analysis of the data from the National Household Sample Survey (PNAD) Continuous in the informal market to understand female participation in this context is also welcome. Another idea is to carry out analyzes based on publicly-held companies to identify the performance of women entrepreneurs. The survey of other hypotheses is also strongly encouraged, as well as a deeper study in areas of engineering and medicine, which was incorporated more recently in the areas studied in this work (STEMM).

Author Contributions: Conceptualization, E.L.G.; methodology, E.L.G. and M.W.L.M.; validation, E.L.G. and M.W.L.M.; writing-review and editing, M.W.L.M. and H.A.C.; supervision, H.A.C. All authors have read and agreed to the published version of the manuscript.

Funding: This research received no external funding.

Conflicts of Interest: The authors declare no conflict of interest.

\section{Abbreviations}

The following abbreviations are used in this manuscript:

$\begin{array}{ll}\text { BI } & \text { Business Intelligence } \\ \text { CBO } & \text { Brazilian Classification of Occupations } \\ \text { CINE } & \text { International Standardized Classification of Education } \\ \text { GDP } & \text { Gross Domestic Product } \\ \text { HEI } & \text { Higher Education Institution } \\ \text { ICT } & \text { Information and Communication Technology } \\ \text { ILO } & \text { International Labor Organization } \\ \text { INEP } & \text { National Institute of Educational Studies and Research Anísio Teixeira } \\ \text { IT } & \text { Information Technology } \\ \text { PNAD } & \text { National Household Sample Survey } \\ \text { RAIS } & \text { Annual Social Information List } \\ \text { SDG } & \text { Sustainable Development Goal } \\ \text { STEM } & \text { Science, Technology, Engineering, and Mathematics } \\ \text { STEMM } & \text { Science, Technology, Engineering, Mathematics, and Medicine } \\ \text { UN } & \text { United Nations } \\ \text { UNESCO } & \text { United Nations Educational, Scientific and Cultural Organization }\end{array}$

\section{References}

1. Klasen, S.; Le, T.T.; Pieters, J.; Silva, M.S. What drives female labour force participation? Comparable micro-level evidence from eight developing and emerging economies. J. Dev. Stud. 2021, 57, 417-442. [CrossRef]

2. Brosio, M.; Langou, G.D.; Rapetti, M. The economic case for reducing gender gaps in the labour market. Management 2018, 22, 1464-1485.

3. Miotto, G.; Polo López, M.; Rom Rodríguez, J. Gender equality and UN sustainable development goals: Priorities and correlations in the top business schools' communication and legitimation strategies. Sustainability 2019, 11, 302. [CrossRef]

4. Ferreira, A.P.; Lucchese, M.M. Computação e linguagem: Uma nova abordagem para aproximar meninas em idade escolar das áreas STEM. In Proceedings of the XIV Women in Information Technology (WIT), Cuiabá, MT, Brazil, 16-19 November 2020; pp. 194-198. [CrossRef] 
5. Antonio, A.; Tuffley, D. The gender digital divide in developing countries. Future Internet 2014, 6, 673-687. [CrossRef]

6. Rivera-Torres, P.; Araque-Padilla, R.A.; Montero-Simó, M.J. Job stress across gender: the importance of emotional and intellectual demands and social support in women. Int. J. Environ. Res. Public Health 2013, 10, 375-389. [CrossRef]

7. Girgus, J.S.; Yang, K.; Ferri, C.V. The gender difference in depression: are elderly women at greater risk for depression than elderly men? Geriatrics 2017, 2, 35. [CrossRef]

8. Kim, A.Y.; Sinatra, G.M.; Seyranian, V. Developing a STEM identity among young women: A social identity perspective. Rev. Educ. Res. 2018, 88, 589-625. [CrossRef]

9. Blackburn, H. The status of women in STEM in higher education: A review of the literature 2007-2017. Sci. Technol. Libr. 2017, 36, 235-273. [CrossRef]

10. Casad, B.J.; Petzel, Z.W.; Ingalls, E.A. A model of threatening academic environments predicts women STEM majors' self-esteem and engagement in STEM. Sex Roles 2019, 80, 469-488. [CrossRef]

11. Keune, A.; Peppler, K.A.; Wohlwend, K.E. Recognition in makerspaces: Supporting opportunities for women to "make" a STEM career. Comput. Hum. Behav. 2019, 99, 368-380. [CrossRef]

12. Sassler, S.; Glass, J.; Levitte, Y.; Michelmore, K.M. The missing women in STEM? Assessing gender differentials in the factors associated with transition to first jobs. Soc. Sci. Res. 2017, 63, 192-208. [CrossRef]

13. Poggesi, S.; Mari, M.; Vita, L.; Foss, L. Women entrepreneurship in STEM fields: literature review and future research avenues. Int. Entrep. Manag. J. 2020, 16, 17-41. [CrossRef]

14. Van Oosten, E.B.; Buse, K.; Bilimoria, D. The leadership lab for women: Advancing and retaining women in STEM through professional development. Front. Psychol. 2017, 8, 2138. [CrossRef] [PubMed]

15. Lee, M.; Yun, J.J.; Pyka, A. How to respond to the fourth industrial revolution, or the second information technology revolution? Dynamic new combinations between technology, market, and society through open innovation. J. Open Innov. 2018, 4, 21. [CrossRef]

16. Odinokaya, M.; Krepkaia, T.; Sheredekina, O.; Bernavskaya, M. The culture of professional self-realization as a fundamental factor of students' internet communication in the modern educational environment of higher education. J. Educ. Sci. 2019, 9, 187. [CrossRef]

17. Setini, M.; Yasa, N.N.K.; Gede Supartha, I.W.; Ketut Giantari, I.; Rajiani, I. The passway of women entrepreneurship: Starting from social capital with open innovation, through to knowledge sharing and innovative performance. J. Open Innov. $2020,6,25$. [CrossRef]

18. Canedo, E.D.; Tives, H.A.; Marioti, M.B. Barriers faced by women in software development projects. Information 2019, 10, 309. [CrossRef]

19. Radović-Marković, M.; Živanović, B. Fostering green entrepreneurship and women's empowerment through education and banks' investments in tourism: Evidence from Serbia. Sustainability 2019, 11, 6826. [CrossRef]

20. Dunn, M.H.; Merkle, L.D. Assessing the impact of a national cybersecurity competition on students' career interests. In Proceedings of the 49th ACM Technical Symposium on Computer Science Education, Baltimore, MD, USA, 21-24 February 2018; ACM: Baltimore, MD, USA, 2018; pp. 62-67. [CrossRef]

21. Hoffman, S.F.; Friedman, H.H. Machine Learning and Meaningful Careers: Increasing the Number of Women in STEM. J. Res. Gend. Stud. 2018, 8, 11-27.

22. Holman, L.; Stuart-Fox, D.; Hauser, C.E. The gender gap in science: How long until women are equally represented? PLoS Biol. 2018, 16, e2004956. [CrossRef]

23. Arnott, D.; Lizama, F.; Song, Y. Patterns of business intelligence systems use in organizations. Decis. Support Syst. 2017, 97, 58-68. [CrossRef]

24. Trieu, V.H. Getting value from Business Intelligence systems: A review and research agenda. Decis. Support Syst. 2017, 93, 111-124. [CrossRef]

25. Vrchota, J.; Řehoř, P.; Maříková, M.; Pech, M. Critical Success Factors of the Project Management in Relation to Industry 4.0 for Sustainability of Projects. Sustainability 2021, 13, 281. [CrossRef]

26. De Cnudde, S.; Martens, D. Loyal to your city? A data mining analysis of a public service loyalty program. Decis. Support Syst. 2015, 73, 74-84. [CrossRef]

27. Hoelscher, J.; Mortimer, A. Using Tableau to visualize data and drive decision-making. J. Account. Educ. 2018, 44, 49-59. [CrossRef] 